\title{
Gender Justice in India: A Feminist Jurisprudential Perspective
}

\author{
Shampa Dev *
}

\section{Abstract}

A perusal of the criminal laws and personal laws reveal that laws adopt a protectionist and paternalistic approach for empowering and providing autonomy to women. This paper initiates a discussion on issues at the core of gender justice. It questions the man-woman dichotomy and asserts that if men and women are fundamentally different as categories, then a single yardstick for measuring justice is wrong. And, if they are not class wise different, and evince only personal traits, then the whole idea of gender justice based on the dichotomy is flawed. This paper further argues that social conditioning restricts the possibility of autonomous decisions. In conclusion, it is argued that laws need to create just social conditions and institutions that guarantee freedom from socially imposed disabilities, and subsequently, strengthen autonomy in decision making.

Keywords: Feminist Jurisprudence, Paternalistic Laws, Patriarchal, Women Empowerment, Autonomy, Gender Justice, India Law

\section{Introduction}

The state has adopted many measures in the form of laws and government schemes for women empowerment. Yet, many women

\footnotetext{
* School of Law, Christ University, Bengaluru, India; shampa.dev@christuniverstiy.in
} 
seem to be dissatisfied (Ministry of Education and Social Welfare, Government of India, 1974)i. In fact, many scholars opine that gender justice is still a mirage. This paper arises out of the need to reassess and explore the laws relating to women in India - to understand why women welfare measurements are not yielding fruits. Preliminary investigation reveals that the approach these laws adopt can be broadly classified as paternalistic that is, these laws dictate what is good for women. They are also protectionist as they extend the support of the state against attacks on a woman's person and property. We understand that these laws regard women as weak and vulnerable and hence adopt the protectionist and paternalistic approach. Several feminists have attacked this underlying assumption. They have argued for the lack of veracity of such claims and have often, through analysis, unravelled the role of social construction in creating such an ideology (Jaisingh, 2004).

Through the following sections, this paper explores the laws relating to the protection of women and their empowerment. It investigates the rationale behind these laws as interpreted by the judiciary in various decisions. This paper draws from the arguments of feminists and evaluates them alongside Rawls' theory of justice (Rawls, 2005). Rawlsian theory justifies the extension of support of the law to the vulnerable, weak or to the disadvantaged group in order to bring them at par with the well-off group. Additionally, this paper employs a Kantian account of reasoning to scrutinise women empowerment laws to explain the social conditioning and the resultant impediment to ensuring women empowerment, women autonomy, and gender justice.

\section{Women empowerment and Indian laws}

Empowerment represents the granting of social, political or economic power to an individual or group. Women empowerment aims to provide women equal opportunities as well. It is the process of supporting women, to help them discover and provide them with the support to assert their personal power. The laws are enacted to empower women by granting them political power and by helping women achieve economic control and authority through education and social upliftment. Women empowerment is essential 
for creating a stronger economy and achieving internationally agreed goals for sustainable development. Laws provide an essential foundation for fulfilling this purpose by creating a constructive environment for growth, and for facilitating women empowerment. An analysis of these laws can provide us a framework of how laws can be categorised. Within the purview of legal analysis, laws can be broadly classified as protectionist or paternalistic. The following paragraphs examine these approaches from a feminist perspective and explore how ideations within legal philosophy could provide us a conceptual framework to address these issues.

\section{a. Protectionist approach}

Criminal laws majorly fall under the purview of this category. The Indian Penal Code declares any form of interference with the body, dignity, honour and marriage, as an offence ${ }^{i i}$. The Indian Evidence Act makes presumptions in favour of women whereas the Criminal Procedure Code formulates safeguards in the interests of women, in cases of arrests. Additionally, a slew of statutes protect the interests of women ${ }^{\mathrm{iii}}$.

In spite of all the protection that the law accords to women, justice is still distant. A closer analysis reveals the paternalistic contours. The provision relating to adulteryiv can be examined here. The courts have interpreted this section, to mean that the woman involved in the adulterous relation does not have any 'voice' in this matter. This interpretation perhaps evokes the 'property' valence of women, wherein, women as commodities can be exchanged and bartered as the property of their husbands. Hence, if a third person interferes with the property, here, the woman and wife, the law considers the husband, to be a victim and extends protection to him. The offense is against the husband, whose wife was being enticed away by a third person. A careful perusal of the provision also reveals that if the husband consents to the third party having sexual intercourse with his wife, then no offense is committed. Such a provision has been the matter of contention, with women vehemently opposing the provision of law (Jaisingh, 2004). The law caters to the 'male' and his concerns. This provision apart from 
treating the woman as an object that belongs to a man also snatches away her autonomy. It ignores the fact that as a person she is capable of having and asserting viewpoints.

Insensitivity towards women's rights can also be perceived in the decisions of the courts, wherein, in many verdicts, the court held that a woman of easy virtue cannot complaint of rapev, or that rape is just an outcome of an uncontrollable lust (AIR, Raju vs State of Karnataka, 1995), that a man experienced which was not in his control to restrain and hence, he should not be severely punished.

Feminist theories maintain that law emerges from patriarchal mindsets to reinforce patriarchal values. The legal subordination of one sex to the other is wrong in itself, and one of the chief hindrances in human development (Mill, 1869). Laws speak of the male experience and portray male norms in the male voice while ignoring women's experiences and voices. Some features of the law may not only be non-neutral in the general sense but also 'male' in the specific sense (Bartlett, 1990) and thereby contributing to women's oppression. Combined with this point about the effects of justice, is an equally cynical thesis about the language of 'justice': namely that one important way in which the politically strong take advantage of the weak is by manipulatively attaching a self-serving sense to this powerful term (Barney, 2017). Callicles (Barney, 2017) argues that it is in the order of nature that the strong take advantage of the weakvi. Finley (1989) argues that even the language used by the law is male legal language, which plays a significant role in the way we comprehend the world around us. Since men have had an overpowering voice in making the laws, defining it and shaping it reflects significantly how they see the 'other'. Even where they accommodate the 'other', by making equality provisions in the laws, they do it in their own light and understanding and hence create a fundamentally flawed perspective as the basis of the laws (Finley, 1989), thereby creating the gendered nature of legal reasoning and language of the law.

Addressing the issue of legislators' bias tiptoeing into law, John Rawls (Rawls, 2005) offers a suggestion. He suggests putting the lawmaker behind the 'veil of ignorance.' In this 'original position,' 
he is ignorant of his standing in the society. He is accorded the knowledge about the society and the discriminatory practices therein and is required to choose principles of justice. In this original position, Rawls argues, that liberty that cannot be absolute and has to be restricted in the interest of liberties for the others (Rawls, 2005). The other principle of justice proposed by Rawls is equality based on the Minimax principle. As much as the whole idea is fictional or a mere thought experiment, nevertheless it highlights one important aspect. Social conditioning, biological conditioning or private interests should be segregated from lawmaking. This will ensure the provision of just laws that endorse liberty and equality.

\section{b. Paternalistic approach}

In the constitutional sphere, laws have adopted a paternalistic approach, using which they dictate what is good for women and ensuring that they get their share. Two main techniques for empowerment can be identified. One is women empowerment by way of affirmative action and the other is enabling autonomous decisions by reserving seats and putting women in decisionmaking roles. There were only 15 women members as against 281 male members in the Constituent Assembly. Two women members, Hansa Mehta and Rajkumari Amrit Kaur were a part of the sub-committee on Fundamental Rights. The most crucial purpose of this committee was to secure fundamental rights for men and women alike. The equality clause was a step towards achieving the same. Furthermore, the Constitution provided the equality of status and of opportunity for women in relation to men.

Marriage, divorce, and inheritance are subject matters that are generally governed by a person's respective religion. It is guided by ritualised practices and is not based on rational argumentation. Within this purview, therefore, what the Constitution offered, it took away as well. It gave the right to equality but effectively diminished the same by granting the right to freedom of religion. Women faced major discrimination in the domain of the personal law. All the personal laws were dictated by religion. It thereby left laws relating to marriage, divorce, inheritance, and succession 
vulnerable to religious dictates. Hansa Mehta and Rajkumari Amrit Kaur were skeptical on the issue and suggested that the right to religion be confined to religious worship, but the constituent assembly blinded by social conditioning refused to accept the suggestive measure. It was widely accepted that personal laws are in the domain of religion and not a matter for secular legislation. Dr. Babasaheb Ambedkar observed that the British had also refrained from interfering in personal laws. Hence, substantive equality for women remained trapped in the patriarchal notions of the state. Later, the courts also refused to read personal laws as laws and held that they are not amenable to be judged by the touchstone of the right to equality provided by the Constitution of India.

\section{i. Affirmative action}

Additionally, the law ensured a protective discrimination in favour of women, to ameliorate their social, economic and political condition and to ensure social justice. Apart from the various laws enacted for the benefit of women, the Ministry of Women and Child Development has adopted many schemesvii for the empowerment, socio-economic development, and equality of women. Though the affirmative action is justified, as it helps in the development of women, yet the very idea rests on the belief that women are weak and require upliftment.

In the domain of labour laws, women are still trapped under the pre-defined gender roles. An example of such a law is the Factories Act of 1948viii. It accommodates interests of women by providing for their welfare in the form of availability of crèches at the office. It overlooks that men might also be similarly in need of welfare measures. It is laudable that the laws are sensitive to the needs of women. But in doing so, the law endorses the patriarchal notion and dictates that women are to take care of children and men are absolved from such responsibility. It ignores the fact that men can be caring or that they may be burdened with a similar task of taking care of children. This facility of the crèche is not available for the male members working in the factory. Radical feminists raise 
serious objections to this and argue that the root cause of women's oppression is in these pre-defined gender roles.

These pre-defined gendered roles may have arisen out of the job allocation between male and female members of the society. Since women gave birth to children and had to nurture the child, they were more closely associated with nature. Her bodily processes identified her and characterised her as closely associated with nurturing and caring (Pattanaik, 2013)ix. Since women were more engaged in caring and nurturing the child, she was expected to stay back at home, attuned to her nature to the various activities centered on the home. Consequently, men had to be the providers. While women are expected to take care of kids and other members of the family including the male members and tend to their needs, men had a role of a hunter-gatherer who is expected to provide for the family. Eventually, men came to be considered strong, determined and aggressive as against the woman who was seen as humble, docile and physically weak.

Job allocation may have arisen out of necessity, but eventually, it got crystallised and became endorsed by the cultural practices of the society. It was the most efficient, economic and a viable solution. It led to the optimal use of resources. Later, women like qualities were valued in women and male-like qualities were valued for men. This led to social conditioning and crytallising of gender-specific roles. Keeping the social roles intact was in the interest of the society and hence any deviation was reprimanded. Both the sexes were expected to fit in their respective defined zones. This only further augmented the strict identities, which came to be observed and perpetuated through generations. Failure to conform led to reprimanding and any deviation was viewed with contempt.

Such gendered roles got embedded in the social institutions and structures. This could be seen through the presence of "maternity leave" in most societies, while "paternity leave" was still a rarity even among the most liberal of nations. What this highlights is the society's notions of gender roles are being reinforced by the systems of the society and perpetuated through it. Women 
experienced oppression in this power play in terms of male domination and women subordination. Feminists militate against patriarchy and male supremacy and argue that a significant overhauling of the societal mindsets was required to rectify this. They view laws as an endorsement of the age-old practice of oppression. They believe laws aren't really fair or provide equal treatment. Hence feminist legal theories are primarily aimed at "understanding and exploring the female experience, figuring out if law and institutions oppose females, and figuring out what changes can be committed to" (Claire, 1992).

\section{ii. Reservations in decision-making roles}

The paternalistic approach of the law also culminated into reserving seats for women in decision-making roles i.e. in municipalities and panchayats. The governing criterion was to ensure equality and to bring women at par with men, which the law simply assumed. This brings to mind another question. Should women be judged according to male standards? If yes, then can equality be achieved when women are brought on equal status with men? It was believed that since men are in decision-making roles, true equality could be achieved when women are also put in decision-making roles. This binary conception of justice demanded parity between members of the society as the true end of justice.

It is contended that this is the fundamental flaw. The application of a binary conception of justice, to bring gender justice, fails as such an argument assumes

1) that this society can be divided into two power opposites, i.e. men and women,

2) that man is at the higher end of the power equation and women are at the lower end, thereby meaning men dominate the women,

3) that the standard of judging the person at the lower end is the eyes of the person at the higher end of the power equation, and, 
4) that gender justice can be achieved only by uplifting the person at the lower end up to the person at the higher end.

This raises another issue - Is this Man-Woman dichotomy justified? Are men and women fundamentally different from each other?

Studies (Watts, 1991) have persistently explained how men and women differ in their nature. They attribute individualistic, confident and aggressive attitudes to men while attributing passive, caring, and submissive attitudes to women.

Radical feminists assert that the man-woman dichotomy exists in terms of male domination and woman subordination. This is the root cause of the contentions. On the other hand, cultural feminists are of the opinion that men and women have different characteristics and these characteristics should determine the role they play in the society. Cultural feminism, though originally evolved from radical feminism, departs from radical feminism in asserting that women are governed by the ethics of care. They would like the essence of being a woman preserved, as well as given due credit, regardless of whether this nurturing trait in the woman is biologically determined or socially conditioned. They assert that women give more importance to co-operation and value relationships and peace.

Hence cultural feminists (Harding, 2004) conclude that women's actions should not be judged by the male standards. Instead, women be respected for the class of values that they represent. They should be put in such roles where these values find expression and enhancement. These values in the woman could be better utilised by placing her in leadership roles. They would allow them to secure all these values in the society thereby contributing to a better world. They speak of women being put into roles they are best suited to.

Carroll Gilligan (1988) explains masculine voice as 'logical and individualistic' and feminine voice as 'caring'. The masculine voice focuses on the justice elements and protection of rights whereas the feminine voice emphasises on interpersonal relationships and taking care of other people. The feminine voice focuses on the care 
perspective. She argued for the integration of the masculine and feminine traits for the realisation of the full potential of humans.

Reverting to the questions at hand - if men and women are fundamentally different from each other then there can be no common yardstick for measuring equality. Men are different in their own domain, and women similarly are different in their own domain. Therefore, it is argued that bringing 'unequals' at par with each other is not a real measure of equality. It is a fundamental principle of equality that categories being compared or evaluated in relation to one another be of commensurate nature and not contrasting. Essentially, men with their own characteristics of being individualistic and strong will grow in their own way whereas women, with their caring and nurturing traits, will grow in their own way. Trying to bring women at par with men would be a flawed attempt at ensuring equality.

\section{Perceived difference between male and female members - Effects of social conditioning}

It may be interesting to note the prevalence of matrilineal societies, in some parts of India. Most commonly known matrilineal societies are the Garo and Khasi tribes ${ }^{x}$ of Meghalaya, a north-eastern state in India. These matrilineal societies experience the reverse kind of social conditioning. Women are considered to be strong and aggressive and the inheritance line is through the female members. Women are seen burdened with all sorts of roles and responsibilities. If women are weak as is the basic assumption in patriarchal societies, then decision-making roles for women is a misnomer. Or the reverse is true, that is, the women need to be considered a strong contender.

Presence of matrilineal societies wherein women apply autonomy is an endorsement of the views of Simone De Beauvoir. That women are weak is a fact of social conditioning. It drives women to think of themselves as weak and handicapped. Hence, they tend to depend on their male counterparts. De Beauvoir asserted that women are capable of free choice. The constant reference to the woman as the 'other' by the patriarchal society has had an adverse 
impact on her autonomy. She feels women are capable of being responsible for themselves and the world around them. Stereotyping women as a 'mystery that is un-understandable' helped men to shirk away from their responsibility. Hence, women have been looked upon as 'female by virtue of a certain lack of qualities' (de Beauvoir, 1949). Alternatively, it has always been understood that men are the default setting whereas women were the recessive gender. She believed that one is not born as a woman but is made one. Women are taught to be caring and nurturing while men are taught to be individualistic.

If Simone de Beauvoir's perspective is indeed true and following her, we assert that men and women are essentially no different as categories, that is, in class characteristics, but display specific characteristics of their individual selves irrespective of their sex, then the application of equality principles to bring women at par with men will reflect a flaw. Justice would be done when each individual has the opportunity and the freedom to grow in the way he wants.

Hence, if it is agreed upon that men and women are fundamentally different from each other, then a common yardstick cannot be employed as a measure. And if men and women are no different from each other, then, the application of any yardstick as against the other is flawed. Thereby, it disrupts the background of legal philosophy underlying women empowerment laws, both protectionist or paternalistic.

Law is a social fact and so are the societal dictates. The societal dictates that arise in the form of customs, laws or norms of conduct is a fact, accepted and followed as true, irrespective of what grants it, its validity. The dictates of culture regardless of the reasoning are accepted as binding without questioning. That acceptance stems from a habit, a behaviour long followed and imbibed, internalised by virtue of the habit and instilled by a habit practiced for long.

Gender justice means that no one can be denied justice or discriminated based on one's gender (Singh, 2001). Laws, as seen above, are heavily tilted in favour of women. However, feminist 
philosophers would disagree that gender justice has been achieved, though laws were made in support of women - protecting them and empowering them. Much of the barriers lie in cultural norms embedded in the minds of people. Though it would be wrong to deny that there has been no improvement in the status of women in the society, it is not enough. The fundamental flaw is in the paternalistic and protectionist dimension of the law itself.

Tracing the origins of women's subordination or the man-woman dichotomy may matter little when compared to tracing out the path to progress. For as much as a woman is caught up in gendered roles, so is a man. The historical blunder of stereotyping men and women has dwarfed the autonomous capacities of women and men alike. It is largely true that women have been at the receiving end of the subordination due to gendered roles, and would have benefited far more than men if that were not the case.

In spite of laws standing for equality, substantive equality has not really been achieved. It retains its status in the formal spheres in the words of the law book. The realisation of autonomy, I argue, would result in real empowerment.

Paternalism interferes with the autonomy of an individual. It snatches away the person's decision-making power and decides on his behalf. The paternal agent prevents harm and promotes good. Liberty is thereby curtailed. State paternalism in laws is very common. Particularly with respect to women, laws have been designed in a manner that treats women as a group that requires protection.

\section{Autonomy}

Legal measures, however, failed to provide autonomy for women. Autonomy means freedom to act and function independently, make informed and free decisions, without the involvement of another. Autonomous agents reason and make their own choices. They act on motives, reasons, and values that are their own.

For Immanuel Kant (Johnson \& Cureton, 2017), actions that are biologically determined or socially conditioned are not really free. Acting autonomously would be acting as per a law one assigns to 80 
oneself. Kant discovered the supreme principle of practical reason. He called it the Categorical Imperative. It provides guidance for human behaviour. Kant asserts that we are intelligible beings capable of making autonomous decisions, even as against our natural inclinations, biological or social conditioning. Since each individual has this power of reasoning, each can exercise his/her reason and arrive at rational, autonomous choices. To determine whether the choices made are rational, Kant provides a formula. This involves acting only on a maxim that can be universalised. It also involves treating individuals as ends and not as means to an end. Kant believes that such rational thinking will lead us all to the same decisions. No conflict will arise as a result of it. Kant's account of reason and procedure of arriving at a right decision directs the person towards introspection. Kant assumes that everyone following similar principles will thereby arrive at the same decision. It warrants the question if such autonomous decisions would be mindful of social needs. Kant asserts that universalising the maxim would accommodate it. It is unclear as to why all would arrive at the same decision. Critics claim that to agree to such a theory would be irrational as they rest on principles of belief that not all could adopt (O'Neill, 2001).

True empowerment results in complete autonomy. If women were to be groomed as autonomous agents, they are to be allowed their own decision-making. The legal framework, therefore, should stop taking decisions on behalf of women. Ideally, the role of law then should get confined to creating social conditions that facilitate autonomous choices.

But as seen earlier, laws are made by men. Men represent the patriarchal and paternalistic mindset. Even where there are ample laws in favour of women, women are still struggling for justice which is an evidence of the inadequacy of laws, in providing autonomy to women. If the malady lies in law-making, the correction of the process starts there.

As discussed earlier, Rawls puts us through a thought process. Provided we achieve the feat of being able to put the legislator in the 'original position', we would have made laws that are 
independent of patriarchal mindsets. But this thought process that puts a man in the 'original position', accords to him a prior knowledge of the society. Autonomous agents in original position cannot really be said to be completely autonomous, as they have been given some knowledge of the society, including the problems therein. The moment he is accorded the knowledge that there is gender injustice in the society, he is compelled to use the law as a tool to reinforce equality.

It is submitted that the very concept of 'gender justice', involves the comparison between the two genders, thereby, assuming that a dichotomy exists. Any measures built around that assumption is fundamentally flawed.

This results in treating men and women as two separate units and paternalistic laws, dictating how women should be empowered and what women should do to progress. Predominance of women in the legislature, would also not answer to the problem of securing autonomy. For as long as the legislators whether men or women are socially conditioned, they can't really be autonomous. Detaching the legislative mind from the social conditioning is the task. The fallouts of social conditioning are faced not only by women but also the men. Where the gendered roles require women to be caring and teach her self-abnegation, men are similarly burdened to be providers and are not accorded paternity leaves nor do they get the facility of a crèche, if they want to care for their children. So for laws to be truly just, they are to be made with a certain sense of objectivity.

To the extent that the laws remove socially imposed disabilities, it could work well. It would facilitate the making of autonomous decisions. Feminist philosophers reject the Kantian and Rawlsian conception of autonomy, as the notion of the self, implicit in it is too atomistic or individualistic. They also raise doubts about whether individualistic autonomy is a value that should be endorsed. But the Kantian account requires one to universalise the maxim arrived at and see whether it respects persons as ends in themselves. Rawlsian account of liberty is also not absolute or 
individualistic. It restricts liberty in the interest of a like liberty for others. Hence the doubt, we argue, is ill-founded.

\section{On making autonomous choices}

Further, it is claimed that if it is accepted that women are biologically conditioned to be caring and by nature value social relationships, then the Kantian and Rawlsian account would deny women the advantages associated with 'being autonomous'. Autonomy and valuing relationships are seen as opposite ideas. Feminists typically look at autonomy from the women's standpoint. These arise wherein the woman makes excessive deference to others' wishes (self-abnegation) or makes adaptive preference formation keeping family interests in primacy, or adopts deformed desires or willingly adopts oppressive gender practices. Conflicting views prevail - that excessive deference is incompatible with autonomy, whereas if the woman is making a choice, she is nevertheless exercising autonomous choice when she willingly subverts her opinions and interests in favour of those of the others. It also might be the case that the woman is socially conditioned and raised to believe and assume subservient roles as a value. On making autonomous choices and forming standardised desires, women often tie their self-worth to extraneous factors like appearance or dressing. These standardised desires are the results of social conditioning and they damage both rational and autonomous choice.

Kant would demand to examine the root cause of the decision. He would reject a decision if it is biologically or socially conditioned. As long as the decision serves another, he would reject it as being a heteronomous decision. True autonomy comes from moving out of inclinations and acting out of duty. So any act of self-abnegation based on inclination (acting out of love and affection) or out of social conditioning (observing socially induced values of sacrifice) fails to be autonomous.

Can everyone be autonomous? Would it entail more friction in the society? That is where the role of reason comes into play. Autonomous decisions do not mean keeping one's interests ahead 
of others. Autonomy requires one to act as per a law one assigns to oneself, that agrees with the clause of universalisation and the clause of considering 'others as ends'. It requires one to act as per duty.

\section{Conclusion}

Furthering the above discussions into workable propositions is necessary. Legal philosophy needs to address the issues that are raised in the above discussions.

Laws should first start with removing the constraints imposed on men and women by the society. It is necessary to tackle individual cases of injustices, instead of laying down homogenised rules for men and women. As depicted earlier, law reforms directed towards bringing women at par with men has not yielded much success. Individuals should be at the core of law reforms. Laws should enable the creation of social institutions and social conditions conducive for everyone to make autonomous choices. Raising the number of women members in parliament will help in reducing paternalistic laws and ensure autonomy to women in deciding for themselves. This will ensure women-friendly laws.

Social engineering is required for the removal of social conditioning. Conscious measures need to be adopted to break free of social conditioning. Having gender neutral laws, promoting gender-neutral values and gender-neutral institutions will go a long way in getting rid of gendered roles for men and women alike.

\section{References}

AIR. (1995). Raju v. State of Karnataka, SC 222.

Barney, R. (2017). Callicles and Thrasymachus. In E. N. Zalta (ed.), The Stanford Encyclopedia of Philosophy. Retrieved from https:// plato.stanford.edu/archives/fall2017/entries/calliclesthrasymachus/.

K. T. Bartlett. (1990). Feminist legal methods. Harvard Law Review, 103, 836-37. Retrieved from http://scholarship.law.duke.edu/cgi/ 1119 
Beauvoir, S. D. (1949/1997). The second sex. (Le Deuxième Sex). (Trans. by H. M. Parshley). London: Vintage Classics. Retrieved from https://www.marxists.org/reference/subject/ethics/debeauvoir/2nd-sex/introduction.htm

Dalton, C. (1992). Deconstructing contract doctrine' in feminist legal theory: Readings in law and gender (Eds.), by K. T. Bartlett \& R. Kennedy New York: Harper Collins.

Finley, L. M. (1989). Breaking women's silence in law: The dilemma of the gendered nature of legal reasoning. Faculty Scholarship Series, Paper 4011. Retrieved from http://digitalcommons.law.yale.edu/ fss_papers / 4011

Jaising, I. (2004). Gender justice and the Supreme court. In B. N. Kirpal, A. H. Desai, G. Subramaniam, R. Dhavan, \& R. Ramachandran (Eds.), Supreme but not infallible: Essays in the honour of the Supreme court of India. Oxford University Press: India.

Johnson, R., \& Cureton, A. (Fall, 2017 edition). Kant's moral philosophy. In E. N. Zalta (Ed.), The Stanford Encyclopedia of Philosophy (Fall 2017 Edition). Retrieved

from https://plato.stanford.edu/archives/fall2017/entries/kant-moral/.

Mill, J. S. (1869). The subjection of women (Vol. 1). London: Longmans, Green, Reader and Dyer Publishers.

Muuss, R. E. (1988). C. Gilligan's theory of sex differences in the development of moral reasoning during adolescence. Adolescence, 23(89), 229-43. Retrieved from https:// www.ncbi.nlm.nih.gov/ pubmed/3381683

O'Neill, O. (2000). Four models of practical reason. In Bounds of Justice, Cambridge: Cambridge University Press, pp. 11-28.

Rawls, J. (1971/2005). A theory of justice. New York: Columbia University Press.

S. Harding. (2004). The feminist standpoint theory reader: Intellectual and political controversies. London: Routledge.

Singh, Y. S. (2001). Gender Justice - A Legal Panorama, a talk delivered in the colloquium on Gender and Law organised by the National Judicial Academy, British Council and Allahabad High Court at JTRI, Lucknow.

Watts, A. (1991). Nature, man, and woman. New York: Vintage Books. 
Williams, G. Kant's account of reason. In E. N. Zalta (Ed.), The Stanford Encyclopedia of Philosophy (Fall 2017 Edition). Retrieved from $<$ https:/ / plato.stanford.edu/archives/win2017/entries/kantreason/>.

i Towards Equality, Report of the Committee on the status of women in India, Ministry of Education and Social Welfare, Government of India, New Delhi December 1974, available at http://pldindia.org/wpcontent/uploads/2013/04/Towards-Equality-1974-Part-1.pdf

ii Causing miscarriage, buying or selling minor for the purpose of prostitution, kidnapping, abducting or inducing woman to compel her marriage, rape, offences relating to marriage, adultery, outraging modesty, subjecting woman to cruelty or driving her to commit suicide or causing harassment to woman by the husband or his relatives are some of the offences, laid down in the Indian Penal Code, 1860 for the protection of women.

iii Dowry Prohibition Act, 1961, The Immoral Traffic Prevention Act, 1956, The Indecent representation of Women Prohibition Act, 1986 and Protection of Women from Domestic Violence Act, 2005 are some of the statutes enacted that extends protection to women.

iv Section 497 - Adultery - Whoever has sexual intercourse with a person who is and whom he knows or has reason to believe to be the wife of another man, without the consent or connivance of that man, such sexual intercourse not amounting to the offence of rape, is guilty of the offence of adultery, and shall be punished with imprisonment of either description for a term which may extend to five years, or with fine, or with both. In such case the wife shall not be punishable as an abettor.

v Recently in Criminal Appeal No. 655 of 2017, order dated 21st September 2017; the Bombay High Court has expressed its disagreement.

vi Callicles has a straightforward and logically valid argument here: (1) observation of nature can disclose the content of 'natural justice'; (2) nature is to be observed in the realms where moral conventions have no hold, viz among states and among animals; (3) such observation discloses the domination and exploitation of the weak by the strong; (4) therefore, it is natural justice for the strong to rule over and have more than the weak. (From http://plato.stanford.edu/entries/callicles-thrasymachus/ last accessed on September 9, 2017)

vii http:// pib.nic.in/newsite/PrintRelease.aspx?relid=132945 measures include Swadhar - short stay homes, working women's hostel, Support to training and employment programme, Rashtriya Mahila Kosh for micro- 
finance, National Mission for Employment of women for all round development, Crèche schemes, Women helpline numbers, Sabla Scheme, ensuring equal remuneration, maternity benefits, improving health and nutrition during motherhood and prevention, prohibition and redressal in case of sexual harassment at workplace.

viii Section 48 of The Factories Act, 1948 makes provision for Crèches -

(1) In every factory wherein more than thirty women workers are ordinarily employed there shall be provided and maintained a suitable room or rooms for the use of children under the age of six years of such women.

(2) Such rooms shall provide adequate accommodation, shall be adequately lighted and ventilated, shall be maintained in a clean and sanitary condition and shall be under the charge of women trained in the care of children and infants.

(3) The State Government may make rules-

(a) prescribing the location and the standards in respect of construction, accommodation; furniture and other equipment of rooms to be provided, under this section;

(b) requiring the provision in factories to which the section applies, of additional facilities for the care of children belonging to women workers, including suitable provision of facilities for washing and changing their clothing;

(c) requiring the provision in any factory of free milk or refreshment or both for such children;

(d) requiring that facilities shall be given in any factory for the mothers of such children to feed them at the necessary intervals.

ix A similar belief is depicted through the story of Ramayana. This period is referred to as the happiest of all times. Careful reading suggests the prevalence of patriarchal system then. Sita depicts the woman who is an embodiment of nature who comes to life through nature, lives in tune with and very close to nature and in the end goes back to nature. Rama is representative of the male world, the man who is the embodiment of the culture that he shapes and perpetuates in the society. He is therefore referred to as the Marayada Puroshattam Ram. Sita is agreeable to the commands of Ram, even when the diktat issued was unjust. Nature can take in its stride the erroneous decisions that culture produces. Stories have always been a reflection of the times of the society mentioned 
therein. For more reading, Devdutt Pattanaik, Sita, Penguin Books India, 2013 ISBN 9780143064329

x The Official Website of East Khasi Hills District, Meghalaya. Retrieved from http://eastkhasihills.gov.in/culture.html 